\title{
Japanese Frontiers programme fillip to research
}

Japan

The Human Frontier Science Program, Japan's answer to Star Wars and Eureka, could be the best thing that has ever happened to bioscience research in Japan. Much will depend on the next few weeks and months as the ministries involved debate the recommendations of foreign and Japanese scientists and try to secure financial support from the Ministry of Finance, Japanese industry and foreign governments.

The Human Frontier Program, as it used to be called, first emerged from the Ministry of International Trade and Industry (MITI) about a year ago (see $\mathrm{Na}$ ture 320, 296; 1986) alongside a similar proposal, the Human and Earth Science Program, put forward by the Science and Technology Agency (STA). Both advocated international research in basic bioscience for the 'benefit of all mankind' and agreed with the Maekawa report, released shortly after, which recommended that Japan should contribute to new science and technology in the 21st century by promoting international collaboration in basic research.

Frontiers is aimed at defusing Western criticism that Japan is only a consumer of the fruits of basic research. There was a hint that the Prime Minister, Mr Yasuhiro Nakasone, would propose the programme at the Tokyo summit in May last year. But competition between the STA and MITI, the vagueness of the Frontiers programme, and a busy summit schedule led to postponement.

Nakasone, who has long been a backer of the life sciences (see Nature 240, 185; 1972), continues to push the programme. Last year, after behind-the-scenes negotiations between seven ministries, Frontiers re-emerged as the Human Frontier Science Program, a compromise, at least in title, between the MITI and STA proposals.

In mid-December, a feasibility study committee and two working groups of top Japanese scientists were created to develop the programme under the leadership of Michio Okamoto, former president of Kyoto University and chairman of the Committee on Policy Matters of the Council for Science and Technology (headed by the prime minister). Several meetings of both the committee and working groups have been held, including two on 29 January and 12 February at which foreign scientists from the summit nations and the European Economic Community were invited to give their views on how the Japanese government programme should be run.

A 94-page report compiled by MITI's Agency of Industrial Science and Technology in November last year formed the basis of discussion. This report proposes the creation of all the necessary components of an android (artificial brain, eyes, organs, muscles and tissue) through the study of functions of the human body. These 'genuine intelligent robots' might help solve the 'software crisis', Japan's inability to produce good software, and help understand 'technostress', an ailment brought on by working at the manmachine interface.

Most of the report's proposals are less ambitious although on a large scale. The first chapter covers the study of biological functions at the molecular and cell level.

The second chapter deals with functions of the whole organism such as hearing, sight, smell, touch, motor function and thinking and the third with the technology to carry out the research, including the development of an X-ray microscope, a 30T NMR, and ion- and electron beamprobes.

But the report represents only MITI's views. Okamoto and several other scientific advisers favour a programme that would place more emphasis on pure research. In contrast, MITI believes that research should have commercial applications and that pure research will not win funding from the Finance Ministry. The problem is deep-rooted. Engineering has dominated Japan's university system since its establishment in the last century, pure science taking a peripheral role, and, for most Japanese, research means applied research.

Among other possible projects now under consideration is sequencing of the whole genome, one of the original proposals for the STA's Human and Earth Science Program. The STA, in collaboration with Seiko, has been developing an automatic DNA sequence analyser, and the leader of this project, who chairs one of the Frontiers working groups, has long advocated automated processing of DNA sequences such as the human genome. Genome sequencing would fit in with the proposed 20-year timescale of Frontiers and there have already been calls from the United States for collaboration with Japan and Europe on this huge project. But there are fears that megasequencing would absorb too large a proportion of the Frontiers budget. MITI is hoping for Y40,000 million ( $\$ 270$ million) a year (although the budget may be less in the beginning). Most of this would have to come from the government, but industry is expected to contribute. Nakasone will almost certainly propose the Frontiers programme at the next summit in Venice in June, and Katsuhiko Umehara, deputy director of MITI's feasibility study, believes that some other countries will contribute funds.
Sir Walter Bodmer, director of research at the Imperial Cancer Research Fund, said at the meeting on 12 February that he thinks "it is most unlikely that within the United Kingdom we would find a large amount of extra money, if any extra money, to support such a program". But there is "enormous scope for collaboration" within the framework of existing activities and institutions, "if the programme is of a high quality and attractive". Other overseas participants concurred.

Both Bodmer and Professor Joshua Lederberg, president of Rockefeller University, urged Japan to include research directed at the understanding of human diseases, such as parasitic, viral and genetic diseases.

According to a tentative plan outlined at the 12 February meeting, Frontiers will take the form of a granting agency (like the Rockefeller Foundation) which will distribute research grants to international research teams; researchers and information will be exchanged through an international fellowship programme for young researchers and international workshops (like the Gordon Conference) and domestic (Japanese) basic research would be considerably enriched and reinforced in line with the programme.

If the programme is implemented and Frontiers supports basic research, it will be a major turnaround in Japanese science policy. Until now, the Finance Ministry has been frugal on funding basic research. But with the backing of two powerful ministries (MITI and STA) and the prime minister, funding of the magnitude envisaged may well be possible.

One hundred and fifty million yen $(\$ 1$ million) has been allotted to the feasibility study in fiscal year 1987 on top of the Y20 million for this fiscal year, a clear indication that the government is committed to Frontiers. And Japan will invite ten eminent scientists from around the world to discuss the programme in a "wise men's conference" at the Royal Society in London on 1 April.

The other five ministries represented at the Frontiers meetings (the Foreign Ministry, the Ministry of Education, Science and Culture, the Health and Welfare Ministry, the Ministry of Agriculture, Forestry and Fisheries and the Ministry of Post and Telecommunications) officially maintain a neutral stance on the programme. But the successful launching of Frontiers at the summit would be in the interests of the Foreign Ministry. The Education Ministry, on the other hand, is worried that Frontiers could cut into its science budget, but that would be counter to the spirit of the programme and the Maekawa report's recommendation to promote basic research. David Swinbanks 